\title{
Kelayakan Peningkatan Tarif Retribusi di Daya Tarik Wisata Taman Sari Water Castle Kota Yogyakarta: Kajian Kelayakan Biaya
}

Desy Rusmaningatia,1, Ida Bagus Suryawana,2

${ }^{1}$ desyrsm@gmail.com, ${ }^{2}$ idabagussuryawan@unud.ac.id

a Program Studi Sarjana Destinasi Pariwisata, Fakultas Pariwisata, Universitas Udayana, JL. Dr. R. Goris, Denpasar, Bali 80232 indonesia

\begin{abstract}
Tamansari Water Castle is a sub-tourist attraction located in the Keraton Yogyakarta complex, this tourist attraction is famous for its heritage buildings and also for its water palace. Since it was opened to tourists on April 1, 1974 many tourists visited this tourist attraction, both domestic and foreign tourists. Since the opening of this tourist attraction for the first time, which has not yet drawn retribution rates to tourists, there have been several times the rate of retribution increases to enter this tourist attraction. So there needs to be research on the feasibility of increasing the levy rate. In this regard, the author tries to examine the "Studi Kelayakan Peningkatan Tarif Retribusi di Daya Tarik Wisata Tamansari Water Castle".

The research method used in this study is quantitative research with comparative matrix analysis techniques, to analyze the feasibility of increasing levy rates in the tourist attraction of Tamansari Water Castle. Sources of data from primary and secondary data, data collection techniques using observation, interviews and literature studies, and interview instruments in the form of interview guidelines. Determination of informants at Tamansari Water Castle in this study using purposive sampling technique, so as to obtain accurate data about the feasibility of increasing levy rates in the tourist attraction of Tamansari Water Castle.

The results of the research obtained were the feasibility of increasing the levy rate in the tourist attraction of Tamansari Water Castle.
\end{abstract}

Keywords: feasibility, tamansari water castle,

\section{PENDAHULUAN}

Retribusi merupakan pungutan daerah sebagai pembayaran jasa atau yang khusus disediakan dan diberikan oleh pemerintah daerah dan pembayar retribusi dapat menikmati langsung dari hasil pembayaran retribusi. Menurut UU No. 28 tahun 2009 , retribusi merupakan pungutan daerah sebagai pembayaran atas jasa atau pemberian izin tertentu yang khusus disediakan dan/atau diberikan oleh Pemerintah Daerah untuk kepentingan pribadi atau badan. Berbeda dengan pajak pusat seperti Pajak Penghasilan dan Pajak Pertambahan Nilai yang dikelola oleh Direktorat Jenderal Pajak, Retribusi Daerah dikelola oleh Badan Pendapatan Daerah (Bapenda).

Daya tarik wisata Tamansari Water Castle terletak 500 meter arah barat daya dari Keraton Yogyakarta. Itulah mengapa Tamansari yang terletak di tengah Kota Yogyakarta memiliki potensi lebih besar untuk dikunjungi wisatawan dan meningkatkan Pendapatan Asli Daerah dari penarikan retribusinya. Dalam perkembangan pariwisata saat ini dan juga melihat peran pariwisata dalam meningkatkan Pendapatan Asli Daerah lewat penarikan retribusinya, maka diperlukan penelitian tentang studi kelayakan peningkatan tarif retribusi di sebuah daya tarik wisata.

Berdasarkan hal tersebut maka peneliti mencoba mengkaji kelayakan peningkatan tarif retribusi di daya tarik wisata Tamansari Water Castle, Kota
Yogyakarta yang nantinya dapet dijadikan rujukan atau acuan oleh daya tarik wisata lain dalam meningkatkan tarif retribusi dalam jangka waktu tertentu.

\section{TINJAUAN PUSTAKA}

Tinjauan pustaka atau telaah hasil penelitian sebelumnya untuk mengetahui kekurangan dan kelebihan penelitian ini. Penelitian-penelitian sebelumnya akan menjadi acuan peneliti. Peneliti tidak menemukan judul yang persis sama dengan penelitian sebelumnya. Diantaranya penelitian yang dilakukan oleh Agus Sudarmaji pada tahun 2000 tentang Analisis Penarifan Retribusi pelayanan Persampahan/Kebersihan Dengan Metoda Activity Based Costing yang memiliki perbedaan di fokusnya dengan penelitian ini. Selanjutnya penelitian yang dilakukan oleh Sunarto dan Reni Dyah Ayu Fatimah pada tahun 2016 tentang Pengaruh Penerimaan Retribusi dan Penetapan Tarif Obyek Wisata Terhadap Pendapatan Asli Daerah (PAD) Kabupaten Gunung Kidul Tahun 2013-2015 yang berfokus pada pengaruh penerimaan tarif retribusi terhdap PAD dan penelitian ini berfokus pada studi kelayakan peningkatan tarif retribusi daya tarik wisata. Dan yang selanjutnya penelitian yang dilakukan oleh Lafitra Marsha Krisnina pada tahun 2017 tentang Studi Evaluasi Kebijakan Retribusi Parkir Berlangganan di Kabupaten Sidoarjo yang berfokus pada retribusi parkir berlangganan dan penelitian ini berfokus pada retribusi daya tarik wisata. Penelitian ini menggunakan beberapa konsep diantaranya 
Vol. 8 No 2, 2020

konsep pariwisata, studi kelayakan, retribusi, daya tarik wisata, dan elemen rencana kepariwisataan untuk mengkaji data-data yang ditemukan oleh peneliti.

Pengertian pariwisata menurut Norval dalam Muljadi dan Nurhayati 2002 adalah keseluruhan kegiatan yang berhubungan dengan masuk, tinggal, dan pergerakan penduduk asing di dalam atau di luar suatu negara, kota, atau wilayah tertentu. Menurut definisi yang lebih luas yang dikemukakan oleh Kodhyat (1983:4) dalam Primadany 2013 pariwisata adalah perjalanan dari satu tempat ke tempat lain bersifat sementara, dilakukan perorangan atau kelompok, sebagai usaha mencari keseimbangan dan kebahagiaan dengan lingkungan hidup dalam dimensi sosial, budaya, alam, dan ilmu.

Umar (2005:8) mendefinisikan studi kelayakan adalah penelitian terhadap rencana bisnis yang tidak hanya menganalisis layak atau tidak layak bisnis dibangun, tapi juga pada saat dioperasionalkan secara rutin dalam rangka pencapaian keuntungan yang maksimal untuk waktu yang ditentukan. Kemudian menurut Kasmir dan Jakfar (2004:19-21) studi kelayakan adalah suatu kegiatan yang mempelajari secara mendalam tentang suatu kegiatan, usaha, dan bisnis dijalankan.

Menurut Munawir (1997) Retribusi merupakan iuran kepada pemerintah yang dapat dipaksakan dan jasa balik secara langsung dapat ditunjuk. Paksaan di sini bersifat ekonomis karena siapa saja yang tidak mersakan jasa balik dari pemerintah tidak akan dikenakan iuran itu. Kemudian diuraikan pula definisi dan pengertian berkaiatan dengan retribusi yaitu dikutip SprouleJones dan White,(1997) mengatakan bahwa retribusi adalah semua bayaran yang dilakukan bagi perorangan dalam menggunkan layanan yang mendatangkan keuntungan langsung dari layanan itu. Lebih lanjut dikatakan bahwa retribusi lebih tepat dianggap pajak konsumsi dari pada biaya layanan bahwa retribusi hanya menutupi biaya opersional saja.

Menurut Undang-Undang No. 10 Tahun 2009 Tentang Kepariwisataan, pengertian Daya Tarik Wisata adalah segala sesuatu yang memiliki keunikan, keindahan, dan nilai yang berupa keanekaragaman kekayaan alam, budaya, dan hasil buatan manusia yang menjadi sasaran atau tujuan kunjungan wisatawan.

Elemen-elemen suatu rencana kepariwisataan oleh Page (1995:171) dalam Agnes (2010:37), disebutkan sebagai berikut: Lingkungan alam dan sosial ekonomi, Daya tarik dan atraksi, Akomodasi, Transportasi, Elemen-elemen kelembagaan, Prasarana lainnya, Fasilitas, utilitas, dan pelayanan wisata lainnya, Pasar wisata domestik dan internasional, Penggunaan prasarana wisata oleh penduduk setempat.

\section{METODE}

Berdasarkan jenisnya, data yang digunakan dalam penelitian ini adalah data kuantitatif data kualitatif. Paradigma dalam penelitian ini adalah kuantitatif dengan menggunakan metode kualitatif dan metode kuantitatif (Anom, dkk., 2019). Sumber data dalam penelitian ini adalah data primer dan data sekunder (Bungin, 2007).

Teknik pengumpulan data yang digunakan dalam penelitian ini diantaranya observasi dan wawancara (Suryawan dkk., 2017), studi kepustakaan dan dokumen (Sugiyono, 2015). Teknik analisis data yang digunakan dalam penelitian ini diantaranya adalah analisis kuantitatif (Kasmir, dkk. 2004). Untuk menganalisis perencanaan pariwisata dan Comparative Matrix yaitu studi sosial yang sering melibatkan banyak pengelompokan untuk mengenali persamaan atau perbedaan bahkan perbandingan, seperti yang ditunjukkan oleh Marzano, Pickering, dan dan Pollock (2001).

\section{PEMBAHASAN DAN HASIL}

\section{A. Fungsi Tamansari}

Tamansari merupakan salah satu bangunan bersejarah Keraton Yogyakarta, didirikan pada Tahun Ehe 1684 Jw (1758M) oleh Sultan Hamengkubuwana I yang memiliki arti "taman yang indah". Tamansari juga disebut dengan water castle atau istana air karena memiliki nilai arsitektur dan keunikan pada lekukan bangunan dan air yang terisi di kolam, tempat ini juga dikelilingi kolam/segaran di sekelilingnya. Tamansari memiliki fungsi diantaranya sebagai tempat pertahanan dan perlindungan, hal ini terlihat dari adanya benteng keliling yang tinggi, adanya baluwer untuk tempat persenjataan, gerbang atau gapura yang dilengkapi dengan tempat penjagaan prajurit atau abdi dalem, dan adanya jalan bawah tanah yang menghubungkan antara satu tempat ke tempat lainnya. Selanjutnya berfungsi sebagai tempat religius, beberapa bangunan di Tamansari difungsikan sebagai aktifitas religi dan meditasi. Selanjutnya Tamansari berfungsi sebagai tempat pesiar atau tempat rekreasi. Hal ini dapat diketahui dari adanya umbul, pasiraman, kolam, segaran, dan taman. Kompleks Tamansari dibagi menjadi empat bagian. Diantaranya: danau buatan di sebelah barat, pemandian umbul binangun di sebelah selatan, pasarean dan kolam garjitawati terletak di bagian selatan kedua, dan bagian timur pertama dan kedua meluas ke arah timur hingga tenggara Kompleks Magangan. 
Vol. 8 No 2, 2020

\section{B. Bangunan Tamansari}

Tamansari memiliki bagian dari setiap bangunannya. Diantaranya adalah Gedong Gapura Hageng, gedong lopak-lopak, pasiraman umbul binangun, gedong sekawan, gedong gapura panggung, gedong temanten, gedong pengunjukan, gerbang kenari, gapura umbulsari, pasarean ledoksari, gedong madaran, pasiraman umbulsari, gedong blawong, gedong garjitawati, gedong carik, pongangan barat, pongangan timur, gerbang sumur gumuling, sumur gumuling, pulo panembung, dan pulo kenanga.

\section{Jumlah Kunjungan Wisatawan}

Dalam penelitian ini, peneliti mendapatkan data rekapitulasi jumlah kunjungan wisatawan selama dua tahun, yakni pada tahun 2017 dan 2018. Adapun jumlah kunjungan akan dijelaskan pada tabel berikut:

Tabel C

Jumlah Kunjungan Wisatawan Tahun 2017

\begin{tabular}{|l|l|l|}
\hline \multirow{2}{*}{\multicolumn{1}{|c|}{ Bulan }} & \multicolumn{2}{c|}{ Jumlah } \\
\cline { 2 - 3 } & \multicolumn{1}{|c|}{ Domestik } & Mancanegara \\
\hline JANUARI & 32.331 & 2.200 \\
\hline FEBRUARI & 30.015 & 3.640 \\
\hline MARET & 43.702 & 3.600 \\
\hline APRIL & 33.659 & 4.501 \\
\hline MEI & 37.889 & 5.648 \\
\hline JUNI & 25.126 & 4.629 \\
\hline JULI & 42.156 & 6.985 \\
\hline AGUSTUS & 35.685 & 7.010 \\
\hline SEPTEMBER & 22.331 & 3.801 \\
\hline OKTOBER & 29.885 & 3.726 \\
\hline NOVEMBER & 26.335 & 3.669 \\
\hline DESEMBER & 53.229 & 4.005 \\
\hline Total & 412.343 & 53.414 \\
\hline
\end{tabular}

Sumber: Pengelola DTW Tamansari 2017

Pada tahun 2017 kunjungan wisatawan ke Tamansari didominasi oleh wisatawan domestik, naik dan turunnya jumlah wisatawan yang mengunjungi daya tarik wisata ini disebabkan oleh high dan low season, serta wisatwan mancanegara yang mengunjungi Yogyakarta, Tamansari khususnya, telah mengunjungi Keraton Yogyakarta, Malioboro, dan Taman Pintar.

Tabel 4.1.

Jumlah Kunjungan Wisatawan Tahun 2018

\begin{tabular}{|c|c|c|}
\hline \multirow{2}{*}{ Bulan } & \multicolumn{2}{|c|}{ Jumlah } \\
\cline { 2 - 3 } & Domestik & Mancanegara \\
\hline JANUARI & 53.662 & 6.254 \\
\hline
\end{tabular}

\begin{tabular}{|l|l|l|}
\hline FEBRUARI & 48.358 & 7.600 \\
\hline MARET & 47.441 & 7.998 \\
\hline APRIL & 38.997 & 8.619 \\
\hline MEI & 41.989 & 8.896 \\
\hline JUNI & 44.398 & 6.000 \\
\hline JULI & 55.698 & 8.607 \\
\hline AGUSTUS & 41.348 & 9.005 \\
\hline SEPTEMBER & 43.568 & 7.506 \\
\hline OKTOBER & 40.258 & 5.556 \\
\hline NOVEMBER & 42.431 & 5.600 \\
\hline DESEMBER & 58.799 & 5.200 \\
\hline Total & 556.948 & 86.841 \\
\hline
\end{tabular}

Sumber: Pengelola DTW Tamansari 2018

Jumlah kunjungan pada tahun 2018 masih didominasi oleh wisatawan domestik, namun jumlahnya meningkat secara signifikan, baik wisatawan domestik maupun wisatawan mancanegara. Hal ini disebabkan oleh semakin membaiknya pengelolaan daya tarik wisata Tamansari dan juga pemeliharaan serta ditambahnya fasilitas-fasilitas pendukung.

\section{Karakteristik Kegiatan Wisata di Daya Tarik Wisata Tamansari Water Castle}

Karakteristik kegiatan wisata dapat dilihat dari elemen-elemen rencana kepariwisataan. Diantaranya:

1. Lingkungan alam dan sosial ekonomi

a. Kondisi lingkungan

Tamansari yang terletak di kota Yogyakarta merupakan dataran rendah dan memiliki tipe iklim "AM dan AW"

b. Kondisi sosial ekonomi

Dampak pariwisata terhadap sosial ekonomi yang ada di Tamansari diantaranya peningkatan pendapatan masyarakat lokal, bertambahnya kesempatan kerja, dan meningkatnya kemampuan bahasa asing (inggris) yang dimiliki masyarakat lokal.

2. Daya tarik dan atraksi

Atraksi yang ada di daya tarik wisata Tamansari diantaranya: bangunan yang memiliki nilai sejarah yang tinggi, pembuatan batik tulis, pembuatan wayang kulit, pembuatan kaos sablon dan ikat celup, pembuatan lukisan, dan spot selfie taman bunga plastik.

\section{Akomodasi}

Akomodasi yang ada di sekitar Tamansari sangatlah memadai, mulai dari home stay, villa, hotel melati sampai hotel berbintang.

Makanan yang ditawarkan di sekitar Tamansaripun beragam dan halal, mulai dari 
Vol. 8 No 2, 2020

makanan tradisional khas Yogyakarta sampai makanan oriental dan continental

\section{Transportasi}

Lokasi Tamansari yang berada di pusat Kota Yogyakarta membuat daya tarik wisata ini mudah dijangkau oleh wisatawan. Beberapa cara yang dapat ditempuh untuk menuju Tamansari diantaranya dapat ditempuh menggunakan kendaraan pribadi seperti mobil, motor, sepeda, maupun mini bus. Selanjutnya wisatawan bisa menggunakan taksi online, andong, becak, maupun trans jogja yang dapat berhenti di halte Malioboro.

5. Elemen kelembagaan

Tamansari resmi dimiliki oleh Keraton Yogyakarta dalam hal ini Kapaskaprajuritan dan dibawahi langsung oleh Bendara Raden Mas Ibnu Prastawa atau Kanjeng Gusti Pangeran Haryo Hadiwinoto yang merupakan Lurah Pangeran Keraton Yogyakarta Hadiningrat. Di dalam struktur Keraton Yogyakarta, KGPH Hadiwinoto menjabat sebagai Penghageng Kawedanan Hageng Punakawan Parastra Budaya dan Penghageng Tepas Panitikismo (yang mengurusi tanah miliik Keraton). Hal ini menyebabkan Tamansari tidak memiliki stakeholder dari pihak swasta, LSM/NGO, BUMN, maupun BUMD.

6. Prasarana Lainnya

Prasarana lain yang ada di sekitar Tamansari diantaranya jalan, pasar wisata, pusat kuliner khas Yogyakarta, halte, dan tempat ibadah.

7. Fasilitas, utilitas, dan pelayanan wisata lain Beberapa fasilitas dan pelayanan wisata yang ada adalah toilet, area parkir, tempat ibadah, rest area, restoran, warung/café, local guide, shuttle car, dan papan surat kabar.

8. Pasar wisata domestik dan internasional Terdapat dua pasar wisata yang terkenal di sekitar Tamansari yakni Pasar Ngasem yang lebih dikenal dengan pasar burung dan Pasar Beringharjo yang merupakan pasar tertua di Kota Yogyakarta.

9. Penggunaan prasarana oleh penduduk setempat

Berdirinya Tamansari saat ini tidak bisa dipisahkan oleh kehidupan masyarakat sekitar, Tamansari yang berada di tengah-tengah perkampungan menyebabkan harus berjalan dan berkembang beriringan dengan masyarakat Kampung Taman. Oleh karena itu pihak Keraton mempersilahkan masyarakat sekitar menggunakan prasarana yang ada, mereka diperbolehkan membuat usaha seperti membuat galeri lukis maupun batik tulis, membuat warung-warung, dan juga bagi masyarakat sekitar yang memiliki kemampuan berkomunikasi yang lebih dipersilahkan menjadi local guide di Tamansari.

Keberadaan Tamansari yang jelas di tengahtengah perkampungan menyebabkan masyarakat sekitar ikut menggunakan prasarana, tidak hanya menggunakan prasarana tapi mereka juga ikut menjaga prasarana yang ada, mereka membuat jadwal kerja bakti dalam rangka menjaga prasarana yang ada.

\section{E. Besar tarif retribusi di daya tarik wisata Tamansari}

Untuk tahun 2019 didapatkan besar tarif retribusi atau harga tiket masuk di daya tarik wisata

Tamansari Water Castle adalah sebagai berikut:

$\begin{array}{ll}\text { Wisatawan domestik } & \text { : Rp. } 5000,00 \\ \text { Wisatawan mancanegara } & \text { : Rp. } 15.000,00 \\ \text { Kamera } & \text { : Rp. } 3.000,00 \\ \text { Pre-Wedding } & \text { : Rp. } 300,000,00 \\ \text { Local Guide } & \text { : Rp. } 20.000,00- \\ 25.000,00 & \end{array}$

\section{F. Matriks perbandingan berpasangan elemen rencana kepariwisataan}

Di dalam matriks perbandingan berpasangan ini, peneliti menggunakan elemen-elemen rencana pariwisata. Dengan keterangan sebagai berikut:

\section{tabel f}

Matrik Perbandingan Berpasangan

\begin{tabular}{|l|l|l|l|l|l|l|l|l|l|l|r|}
\hline & 1 & 2 & 3 & 4 & 5 & 6 & 7 & 8 & 9 & jml & bobot \\
\hline 1 & & 3 & 3 & 2 & 3 & 1 & 2 & 3 & 3 & 20 & 0,14 \\
\hline 2 & 1 & & 1 & 1 & 3 & 2 & 2 & 1 & 2 & 13 & 0,09 \\
\hline 3 & 1 & 3 & & 1 & 3 & 1 & 3 & 2 & 1 & 15 & 0,1 \\
\hline 4 & 2 & 3 & 3 & & 3 & 2 & 3 & 3 & 2 & 21 & 0,15 \\
\hline 5 & 1 & 1 & 1 & 1 & & 1 & 2 & 2 & 1 & 10 & 0,07 \\
\hline 6 & 3 & 2 & 3 & 2 & 3 & & 3 & 2 & 2 & 20 & 0,14 \\
\hline 7 & 2 & 2 & 1 & 1 & 2 & 1 & 2 & 2 & 13 & 0,09 \\
\hline 8 & 1 & 3 & 2 & 1 & 2 & 2 & 2 & & 15 & 0,1 \\
\hline 9 & 1 & 2 & 3 & 2 & 3 & 2 & 2 & 2 & 17 & 0,12 \\
\hline \multicolumn{2}{|l|}{ TOTAL }
\end{tabular}

Sumber: Hasil Penelitian 2019

keterangan:

1.lingkungan alam dan sosial ekonomi

2. daya tarik dan atraksi

3. akomodasi

4.transportasi

5. elemen kelembagaan

6. prasarana lain 
Vol. 8 No 2, 2020

7.fasilitas, utilitas, dan pelayanan wisata

8. pasar wisata domestic dan internasional

9. penggunaan prasarana lain oleh penduduk setempat

Pemberian nilai pada matrik ini ditentukan oleh peneliti, dengan keterangan nilai 1 berarti lebih buruk, 2 sama baik, dan 3 untuk lebih baik. Lalu nilainilai dari setiap elemen dijumlahkan. Untuk mencari bobot, nilai dari tiap elemen harus dibagi dengan total keseluruhan nilai dari setiap elemen. Untuk total keseluruhan dari bobot harus 1 .

\section{G. Comparative matrix}

Dalam penelitian ini, peneliti menggunakan 2 daya tarik wisata lain yang dinilai memiliki beberapa elemen yang sama dengan daya tarik wisata Tamansari, lokasi yang berdekatan, dan menjadi tujuan utama wisatawan yang akan atau sesudah mengunjungi daya tarik wisata Tamansari Water Castle. 2 daya tarik wisata ini disimpulkan dari beberapa wawancara kepada wisatawan yang sedang mengunjungi Tamansari Water Castle. 2 daya tarik wisata tersebut adalah Keraton Yogyakarta dan Taman Pinter Yogyakarta. Nilai dari setiap elemen di masing-masing daya tarik wisata dijelaskan dalam tabel berikut:

\section{tabel G}

\section{Comparative Matrix}

\begin{tabular}{|c|c|c|c|}
\hline Elemen & $\begin{array}{c}\text { Keraton } \\
\text { Yogyakarta } \\
\text { (A) }\end{array}$ & $\begin{array}{c}\text { Taman } \\
\text { sari (B) }\end{array}$ & $\begin{array}{c}\text { Taman } \\
\text { Pintar } \\
\text { (C) }\end{array}$ \\
\hline $\begin{array}{c}\text { Lingkungan alam dan } \\
\text { sosial ekonomi }\end{array}$ & $1,40 \mathrm{~km} 2$ & $\begin{array}{c}0,1 \\
\mathrm{~km} 2\end{array}$ & $\begin{array}{c}0,012 \\
\mathrm{~km} 2\end{array}$ \\
\hline Daya Tarik dan atraksi & 9 & 6 & 15 \\
\hline Akomodasi & \pm 51 & \pm 51 & \pm 51 \\
\hline Transportasi & $1,5 \mathrm{~km}$ & $2 \mathrm{~km}$ & $1 \mathrm{~km}$ \\
\hline Elemen kelembagaan & 1 & 2 & 3 \\
\hline Prasarana lain & 5 & 4 & 5 \\
\hline $\begin{array}{c}\text { Fasilitas, utulitas, dan } \\
\text { pelayanan wisata }\end{array}$ & 7 & 9 & 9 \\
\hline $\begin{array}{c}\text { Pasar wisata domestik } \\
\text { dan internasional }\end{array}$ & 2 & 2 & 2 \\
\hline $\begin{array}{c}\text { Penggunaan } \\
\text { parasarana oleh } \\
\text { penduduk setempat }\end{array}$ & 4 & 6 & 2 \\
\hline
\end{tabular}

Sumber:Hasil Penelitian 2019

Nilai-nilai yang diberikan di setiap elemen dalam matriks diatas adalah nilai yang diberikan oleh peneliti, untuk nilai elemen lingkungan alam dan sosial ekonomi diberikan berdasarkan luas area masing-masing daya tarik wisata, nilai elemen daya tarik dan atraksi diberikan berdasarkan jumlah atraksi yang ada di setiap daya tarik wisata, nilai elemen dari akomodasi diberikan berdasarkan jumlah akomodasi yang ada di sekitar tiap-tiap daya tark wisata, nilai transportasi diberikan berdasarkan jarak setiap daya tarik wisata dari pusat pemerintahan Yogyakarta yang berada di sekitar Jalan Malioboro dan titik $0 \mathrm{~km}$ Yogyakarta, untuk nilai elemen kelembagaan diberikan berdasarkan jumlah stakeholder yang menaungi daya tarik wisata tersebut. Dari pemerintah, swasta, maupun masyarakat lokal. Selanjutnya nilai untuk elemen prasarana lain diberikan berdasarkan jumlah prasarana penunjang yang ada di sekitar masingmasing daya tarik wisata, selanjutnya nilai untuk elemen fasilitas, utulitas, dan pelayanan wisata diberikan berdasarakan jumlah fasilitas yang ada di setiap daya tarik wisata. Nilai untuk elemen pasar wisata domestik dan internasional diberikan berdasarkan ada atau tidaknya serta jumlah pasar wisata yang ada di sekitar masing-masing daya tarik wisata, yang terakhir nilai untuk elemen penggunaan prasarana oleh penduduk setempat diberikan berdasarkan jumlah prasarana yang digunakan oleh masyarakat lokal setiap daya tarik wisata.

Selanjutnya, setelah mendapatkan nilai masing-masing dari setiap daya tarik wisata, akan dicari hasil nilai index dari setiap elemen di masingmasing daya tarik wisata dengan cara mengalikan nilai yang ada di comparative matrix dengan bobot dari setiap elemen yang ada pada matrik perbandingan berpasangan. Untuk setiap nilai index comparative matrix akan dijelaskan pada tabel berikut:

\section{tabel G}

\section{Index Comparative Matrix}

\begin{tabular}{|c|c|c|c|}
\hline Elemen & $\begin{array}{c}\text { Keraton } \\
\text { Yogyakarta } \\
\text { (A) }\end{array}$ & $\begin{array}{c}\text { Taman } \\
\text { sari } \\
\text { (B) }\end{array}$ & $\begin{array}{c}\text { Taman } \\
\text { Pintar } \\
\text { (C) }\end{array}$ \\
\hline $\begin{array}{c}\text { Lingkungan alam } \\
\text { dan sosial ekonomi }\end{array}$ & $\begin{array}{c}1,40 \times 0,14= \\
0,196\end{array}$ & $\begin{array}{c}0,1 \times 0 \\
14= \\
0,014\end{array}$ & $\begin{array}{c}0,012 \mathrm{x} \\
0,14= \\
0,0016 \\
8\end{array}$ \\
\hline $\begin{array}{c}\text { Daya Tarik dan } \\
\text { atraksi }\end{array}$ & $\begin{array}{c}9 \times 0,09=0,8 \\
1\end{array}$ & $\begin{array}{l}6 \times 0,09 \\
=0,54\end{array}$ & $\begin{array}{c}15 \times 0,0 \\
9= \\
1,35\end{array}$ \\
\hline Akomodasi & $51 \times 0,1=5,1$ & $\begin{array}{c}51 \times 0,1 \\
=5,1\end{array}$ & $\begin{array}{c}51 \times 0,1 \\
=5,1\end{array}$ \\
\hline Transportasi & $\begin{array}{c}1,5 \times 0,15= \\
0,225\end{array}$ & $\begin{array}{c}2 \times 0,15 \\
=0,3\end{array}$ & $\begin{array}{c}1 \times 0,15 \\
= \\
0,225\end{array}$ \\
\hline $\begin{array}{c}\text { Elemen } \\
\text { kelembagaan }\end{array}$ & $\begin{array}{c}1 \times 0,07=0,0 \\
7\end{array}$ & $\begin{array}{l}2 \times 0,07 \\
=0,14\end{array}$ & $\begin{array}{l}3 \times 0,07 \\
=0,21 \\
\end{array}$ \\
\hline Prasarana lain & $5 \times 0,14=0,7$ & $\begin{array}{l}4 \times 0,14 \\
=0,56 \\
\end{array}$ & $\begin{array}{c}5 \times 0,14 \\
=0,7\end{array}$ \\
\hline $\begin{array}{c}\text { Fasilitas, utulitas, } \\
\text { dan pelayanan } \\
\text { wisata }\end{array}$ & $\begin{array}{c}7 \times 0,09=0,6 \\
3\end{array}$ & $\begin{array}{l}9 \times 0,09 \\
=0,81\end{array}$ & $\begin{array}{l}9 \times 0,09 \\
=0,81\end{array}$ \\
\hline
\end{tabular}


Vol. 8 No 2, 2020

\begin{tabular}{|c|c|c|c|}
\hline $\begin{array}{c}\text { Pasar wisata } \\
\text { domestik dan } \\
\text { internasional }\end{array}$ & $2 \times 0,1=0,2$ & $\begin{array}{c}2 \times 0,1= \\
0,2\end{array}$ & $\begin{array}{c}2 \times 0,1= \\
0,2\end{array}$ \\
\hline $\begin{array}{c}\text { Penggunaan } \\
\text { parasarana oleh } \\
\text { penduduk setempat }\end{array}$ & $\begin{array}{c}4 \times 0,12=0,4 \\
8\end{array}$ & $\begin{array}{c}6 \times 0,12 \\
=0,72\end{array}$ & $\begin{array}{c}2 \times 0,12 \\
=0,24\end{array}$ \\
\hline$\Sigma$ & 8,41 & 8,38 & 8,83 \\
\hline
\end{tabular}

Dalam matrik diatas dijelaskan index nilai dari setiap elemen yang telah dipaparkan dalam matrik sebelumnya, yang kemudian nilai dari setiap elemen dikalikan dengan bobot yang didapat dari matrik perbandingan berpasangan, setelah dikalikan dengan bobot akan didapatkan nilai dari masingmasing elemen dari setiap daya tarik wisata. Nilainilai tersebut dijumlahkan akan didapatkan nilai total dari masing-masing daya tarik wisata yang nantinya akan dijadikan perbandingan dengan tarif retribusi atau harga tiket masuk dari daya tarik wisata Keraton dan Taman Pintar yang masing-masing sebesar Rp.7.000,00 dan Rp.20.000,00 untuk dapat mencari besaran tarif retribusi yang layak di daya tarik wisata Tamansari Water Castle.

\section{H. Kelayakan tarif retribusi}

$$
\frac{\text { jumlah index dtw } A}{\text { tarif retribusi dtw } A}: \frac{\text { jumlah index TSWC }}{x}
$$

\section{$\underline{X:}$ Tarif retribusi yang layak di daya tarik wisata Tamansari Water Castle}

Dalam penelitian ini, peneliti menggunakan perbandingan jumlah index dan tarif retribusi pada daya tarik wisata Keraton Yogyakarta untuk mencari besar tarif retribusi yang layak di daya tarik wisata Tamansari Water Castle. Karena menurut peneliti Tamansari Water Castle memiliki beberapa elemen yang sama dengan Keraton Yogyakarta.

Untuk perbandingan index dan tarif retribusinya adalah sebagai berikut:

$$
\begin{aligned}
\frac{8,41}{7000}: \frac{8,38}{X} \\
8,41 X=58.660 \\
X=\frac{58.660}{8,41} \\
X=6.975 \\
=\underline{\mathbf{7 . 0 0 0}}
\end{aligned}
$$

Dengan perbandingan tersebut diperoleh hasil sebesar Rp.6.975,00 (enam ribu sembilan ratus tujuh puluh lima rupiah) yang dibulatkan menjadi Rp. 7.000,00 (tujuh ribu rupiah) untuk tarif retribusi atau harga tiket masuk wisatawan domesstik di Tamansari Water Castle.

Dengan melihat pertimbangan-pertimbangan elemen perencanaan pariwisata dan hasil dari penghitungan menggunakan metode comparative matrix dapat disimpulkan bahwa tarif retribusi di daya tarik Wisata Tamansari Water Castle untuk saat ini adalah TIDAK LAYAK.

Tidak layaknya tarif retribusi yang ada di daya tarik wisata ini bukan berarti tarif retribusi atau harga tiket masuk saat ini terlampau mahal, dengan melihat perbandingan-perbandingan di atas, bisa disimpulkan bahwa seharusnya pihak pengelola menaikkan tarif retribusi atau harga tiket masuk yang semula Rp.5.000,00 (lima ribu rupiah) untuk wisatawan domestik, menjadi Rp.7.000,00 (tujuh ribu rupiah) dengan menggunakan pertimbangan elemen perencanaan pariwisata dan perhitungan menggunakan metode comparative matrix.

\section{PENUTUP}

\section{A. Kesimpulan}

Berdasarkan hasil dari pembahasan di atas, maka dapat disimpulkan beberapa hal sebagai berikut:

1. karakteristik kegiatan wisata di Daya Tarik Tamanari (Water Castle) dapat dilihat dari Sembilan elemen rencana kepariwisataan, diantaranya:

a. lingkungan alam dan social ekonomi

b. daya Tarik dan atraksi

c. akomodasi

d. transportasi

e. elemen-elemen kelembagaan

f. prasarana lainnya

g. fasilitas,utilitas, dan pelayanan wisata

h. pasar wisata domestik dan internasional

i. penggunaan prasarana oleh penduduk setempat

2. Dengan perbandingan antara index dan tarif retribusi di daya tarik wisata Keraton Yogyakarta dengan index di daya tarik wisata Tamansari Water Castle diperoleh hasil sebesar Rp.6.975,00 (enam ribu Sembilan ratus tujuh puluh lima rupiah) yang dibulatkan menjadi Rp. 7.000,00 (tujuh ribu rupiah) untuk wisatawan domestik. Dengan melihat pertimbangan-pertimbangan elemen perencanaan pariwisata dan hasil dari penghitungan menggunakan metode comparative matrix dapat disimpulkan bahwa tarif retribusi di daya tarik Wisata Tamansari Water Castle untuk saat ini adalah TIDAK LAYAK 
Vol. 8 No 2, 2020

\section{B. Saran}

Berdasarkan hasil penelitian di atas, penulis menyarankan beberapa hal yang kiranya bisa diterapkan oleh seluruh lembaga yang bergerak pada bidang pariwisata. Adapun saran yang dimaksud adalah sebagai berikut :

a. Saran untuk pemerintah Daerah

Berdasarkan hasil penelitian yang dilakukan, peneliti menemukan beberapa local guide yang tidak memiliki lisensi dan bahkan memiliki sikap yang sedikit kurang sopan kepada wisatawan yang tidak mnggunakan jasanya, Saran untuk pemerintah adalah sebaiknya pemerintah mengadakan pelatihan atau workshop terutama pelatihan tentang hospitality untuk masyarakat lokal yang menjadi pramuwisata atau local guide agar mereka memiliki pengetahuan yang lebih mendalam tentang pengembangan kepariwisataan dan juga hospitality. Pengetahuan yang lebih mendalam ini tentunya akan semakin mengembangkan profesionalisme pengelolaan atraksi di Daya Tarik Wisata Tamansari Water Castle

b. Saran untuk Masyarakat Lokal

Tamansari Water Castle merupakan salah satu daya tarik wisata yang sangat diminati di Kota Yogyakarta, lokasi Tamansari yang yang berada di tengah-tengah perkampungan menyebabkan lebih banyaknya interaksi antara masyarakat lokal dengan wisatawan, saran untuk masyarakat lokal di Kampung Taman yakni agar masyarakat tidak membeda-bedakan antara wisatawan domestik dan mancanegara.

c. Saran untuk Akademisi

Dari penelitian yang telah dilakukan, peneliti menyarankan kepada para akedemisi untuk meneliti lebih luas tentang retribusi di daya Tarik wisata, contohnya penelitian mengenai pentingnya sebuah daya Tarik wisata menarik retribusi pada wisatawan karena hal ini juga akan memberikan pengaruh terhadap Pendapatan Asli Daerah (PAD)

d. Saran untuk Pengelola Daya Tarik Wisata Tamansari Water Castle

Dari hasil penelitian ini, telah didapatkan kesimpulan bahwa tarif retribusi yang berlaku saat ini adalah TIDAK LAYAK, maka peneliti menyarankan kepada pengelola untuk mengkaji ulang tarif retribusi atau harga tiket masuk untuk wisatawan domestik di daya tarik wisata Tamansari Water Castle dengan menggunakan pertimbangan-pertimbangan yang ada dalam penelitian ini. Dan pada matriks perbandingan berpasangan didapatkan bahwa nilai elemen kelembagaan adalah 1, maka peneliti meyarankan kepada pihak pengelola untuk lebih mengoptimalkan kelembagaan yang ada di Tamansari Water Castle kedepannya.

\section{DAFTAR PUSTAKA.}

Anom, M. Par., Dr. Drs. I Putu dan Mahagangga, M. Si., S.Sos., I Gusti Agung Oka. 2019. Handbook Ilmu Pariwisata Karakter dan Prospek. Jakarta: Prenada Media (Divisi Kencana).

Bungin, Burhan. 2007. Analisis Data Penelitian Kualitatif. Jakarta: PT Grafindo Persada.

Devas, Nick, dan kawan-kawan. 1989. Keuangan Pemerintah Daerah Indonesia. Jakarta: UI Press.

Kasmir dan Jakfar, 2004. Studi Kelayakan Bisnis, Jakarta: Prenada Media.

Kasmir dan Jakfar, 2013. Studi Kelayakan Bisnis. (edisi revisi) Jakarta: Kencana.

Marzano, R. J., Pickering, D., \& Pollock, J. E. 2001. Classroom Instruction That Works (research strategies for increasing student achievement). Mc.Rell

Oka, A, Yoeti. 1996. PengantarIlmuPariwisata. Angkasa, Bandung

Pleanggra, Ferry. 2012. Analisis Pengaruh Jumlah Obyek Wisata, Jumlah Wisatawan dan Pendapatan Perkapita Terhadap Pendapatan Retribusi Obyek Pariwisata 35 Kabupaten/Kota di Jawa Tengah (Skripsi, Universitas Diponegoro)

Primadany, Sefira Ryalita, dkk. 2013. Analisis Strategi Pengembangan Pariwisata Daerah (Studi Pada Dinas Kebudayaan Dan Pariwisata Daerah Kabupaten Nganjuk).Fakultas Ilmu Administrasi, Universitas Brawijaya, Malang :Jurnal Administrasi Publik (JAP), Vol. 1, No. 4, Hal. 135-143.

Sugiyono, 2015. Metode Penelitian Kuantitatif, Kualitatif dan R\&D. Bandung : Alfabeta

Sulistya, Bima Albertus. 2016. Tren Perkembangan Pariwisata Daerah Istimewa Yogyakarta Perode 2006-2014 (Skripsi, Universitas Sanata Dharma).

Suryawan, I. B., \& Mahagangga, I. G. A. O. (2017). Penelitian Lapangan 1. Denpasar: Cakra Media dan Fakultas Pariwisata Universitas Udayana.

Tamansari, 2019. Jumlah Kunjungan Wisatawan. YogyakartaDaerah Istimewa Yogyakarta

Umar, Husein. 2005. Studi Kelayakan Bisnis. Edisi-3. Jakarta: PT. Gramedia Pustaka Utama

Yuliasri, Agnes. 2005. Prioritas Pengembangan Obyek-Obyek Wisata Air di Kawasan Rawa Pening Kabupaten Semarang (Tugas Akhir, Universitas Diponegoro) 